\title{
Does coercive pressure improve construction quality? The mediating role of organizational learning
}

\author{
Zhi-Hong Song \\ Institute of Management and Decision \\ Shanxi University. China \\ Yangyuan Chen \\ School of Economics and Management \\ Shanxi University. China \\ Dong-Mei Lee \\ School of Management and Decision \\ Shanxi University. China
}

\begin{abstract}
Combining institutional theory and organizational learning theory, the article develops a conceptual model which describes the relationships among coercive pressure, organizational learning, and construction quality. Data were then collected via 268 valid questionnaires from construction firms located in Taiyuan in central China. Hypotheses in the conceptual model were tested with structural equation modeling. The empirical results reveal that: (1) coercive pressure has a significant positive impact on organizational learning; (2) organizational learning has a significant positive impact on construction quality; (3) organizational learning mediates the relationship between coercive pressure and construction quality. The empirical results may provide implications for Chinese construction firms aiming at improve construction quality.
\end{abstract}

Key words: Coercive pressure, Organizational learning, Construction quality, Structural equation modeling

JEL Class : M19, L15

\section{INTRODUCTION}

As Chinese economy continues to grow rapidly, the construction industry has boomed during the last decade. However, construction quality defects resulting from cheating in work and cutting down on materials have occurred from time to time, which may prove to be hidden troubles for the public. On April 4, 2014, a 5-storey apartment building in Fenghua city, Zhejiang province, China, collapsed with one people dead and six people injured due to the construction quality problems. In order to strengthen the quality of construction projects and protect the safety of the public, the Ministry of Housing and Urban-Rural Development of the People's Republic of China (MOHURD) has launched a series of actions against construction quality problems in recent years. The MOHURD started a two-year action plan on construction quality control in 2014 by implementing the life-long quality responsibility of the project leaders and cracking down the illegal subcontracting and other illegal activities. Faced with the coercive pressure imposed by the government, firms have to adopt appropriate quality control strategies to maintain organizational legitimacy and enhance their competitive edge (Dowling \& Pfeffer 1975; Ashforth \& Gibbs 1990). 
As the firm is not an "atomic" actor, its behaviors are influenced and shaped by the social background. The firm must meet the demands of the stakeholders from external environment to gain their supports in order to maintain sustainable development (Ingram \& Silverman, 2002). Previous literatures have found that coercive pressure from the government contributes to improve environmental management practices and quality management performance (Jennings \& Zandbergen 1995; Khanna 2002; Lee et al. 2010). Jennings \& Zandbergen (1995) argue that coercive pressure from regulatory authorities is more likely to induce firms to adopt environmental management practices. Using patent data as an indicator of innovation, Taylor et al. $(2003,2005)$ show that the level of innovative activities in flue gas desulfurization (FGD) technology increased with the passage of the New Source Performance Standards.

To sum up, previous literatures emphasize the link between coercive pressure and construction quality, and agree that strict coercive pressure imposed by the government may contribute to improve construction quality. The paper takes Chinese construction industry as the research context and explores the influence of coercive pressure on construction quality. The paper argues that the coercive pressure from the government may be transformed or screened by firms, leading to different perceptions and interpretations on the same coercive pressure. The difference between "objective pressures" and "perceived pressures" then leads to different responses and construction quality. In other words, coercive pressure and organizational learning process that transforms "objective pressures" to "perceived pressures" are the main factors affecting construction quality.

In line with this idea, the paper attempts to examine the relationship among coercive pressure, organizational learning and construction quality. Combining institutional theory and organizational learning theory, the paper takes Chinese construction industry as the research context, which are characterized by high resources consumption, high waste and heavy environmental burden. The rest of the paper is structured as follows. Part 2 puts forward theoretical background and research hypotheses. Part 3 describes data sources and variable measurements. Part 4 uses the structural equation model to test the hypotheses proposed in Part 3 and discusses the empirical results. Part 5 summarizes the conclusions, and put forward managerial implications, research limitations and directions for further research.

\section{THEORETICAL BACKGROUND AND RESEARCH HYPOTHESES \\ Theoretical background}

Institutional theory holds that organization is not a closed system. The structure and behavior of an organization will be influenced by other organizations in institutional environment. The institution consists of series of laws and norms and plays a constraining role as the organization pursues its goal of maximizing benefits. Institutional theory emphasizes the importance of legitimacy. Suchman (1995) emphasizes that legitimacy is the objective existence of subjective creation, which can enhance the organization's stability and credibility, which is also conducive for firms to seek positive support from the public. The influence of institutional environment on organizational structure or behavior in order to acquire legitimacy (Zhu \& Sarkis, 2007) and resource acquisition is referred as the institutional pressure (Yiu \& Makino, 2012). Coercive pressure refers to the formal or informal pressure imposed by coercive authorities, such as government agencies, regulatory agencies and legal authorities.

Organizational learning occurs when the firm develops new knowledge and insights from the common experiences of people in the organization, and it has the potential to influence the range of organizational behaviors and improve the firm's capabilities (Huber, 1991; Slater \& 
Narver, 1995). Fiol \& Lyles (1985) argue that organizational learning is the process of improving behavior by acquiring and understanding knowledge. Levitt \& March (1988) emphasize that organizational learning forms conceptual frameworks and paradigms through induction, which can transform direct and indirect historical experience into daily norms that guide organizational behavior. Based on organizational behavior theory, March (1991) points out that firms may try to maintain an appropriate balance between exploitative learning and exploratory learning. Dodgson (1993) argues that organizational learning includes both the process and the result. On the one hand, organizational learning may contribute to establish and supplement organizational knowledge. On the other hand, organizational learning may improve organizational efficiency, adapt to the uncertain demands, solve potential conflicts, and enhance competitiveness by promoting employee skills. As continuous improvement practices aimed at reducing and eliminating waste, quality management systems, just-intime(JIT), and environmental management systems, are fundamental to organizational learning practices(Zhu et al.,2012).

\section{Research hypotheses}

\section{The impact of coercive pressure on organizational learning}

Coercive pressure is the formal or informal pressures imposed by government regulatory agencies (Steadmanet al., 1995; DiMaggio \& Powell,1983). For example, because the legal framework affects firms' behaviors, firms may quickly respond to government orders. In MNCs, Subsidiary must adopt the accounting practices, performance evaluation and budget planning that conform to the policy of the MNCs. Many service infrastructures, such as telecommunications and transportation, are usually provided by monopolies, and monopolies may exert pressures on the organizations using these infrastructures.

Previous studies have found that coercive pressure positively affects organizational learning (Clemens \& Douglas, 2006; Lee et al.,2010). Faced with regulatory pressures for clean production, construction firms with high-energy consumption may adopt technology and process to improve production efficiency and construction quality through continuous learning. Zhu et al. (2012) confirms that the domestic coercive pressure significantly affects organizational learning after controlling firm scale, industry and ownership structure. Lee et al. (2010) show that the high regulatory standards under the technology-forcing regulation played an important role in forcing technological innovations and determining subsequent direction of technological change. This leads us to hypothesize that:

H1: Coercive pressure has a positive impact on organizational learning.

\section{The impact of coercive pressure on construction quality}

Based on the institutional literature, coercive pressure affects the quality management performance of firms (Berrone \& Gomez-Mejia, 2009). The ISO9000 issued by the International Organization for Standardization (ISO) mentions that " The quality of an organization's products and services is determined by its ability to satisfy customers and the intended and unintended impact on relevant interested parties.".

Roome \& Wijen (2006), Kassinis \& Vafeas (2006) argue that, as the most important external stakeholders, the local government authorities control the resources by collecting taxes and providing infrastructures and taxation. The regulatory regulations issued by the General Administration of Quality Supervision, Inspection and Quarantine of the People's Republic of China have become increasingly severe. In order to avoid penalties, bad records and tighter supervision, which result from poor quality management practices, firms may try to improve the construction quality. They may carry out more active quality management practices in the face of the greater coercive pressure (Zhu \& Sarkis, 2007). If firms don't face coercive 
pressure, they may not be willing to take the initiative to implement the active quality management practices because of the associated costs. In other words, lack of coercive pressure may cause firms to lower the level of construction quality. We therefore hypothesize:

H2: Coercive pressure has a positive impact on construction quality.

\section{The impact of organizational learning on construction quality}

Organizational characteristics affect how firms deal with coercive pressure which then affects the quality management practice and the level of construction quality. First, firms may interpret institutional discourse based on their past experience, organizational culture and market orientation. Faced with the changing environment, it is difficult for firms who ignore organizational learning to transform the institutional discourse to management practice quickly. Second, there may be conflicting institutional pressures in the same organization field, and it is difficult to achieve harmony in many cases. The differences in values held by firms lead to differences in interpretation of the common institutional discourse and responses to conflicting coercive pressures. Under such circumstances, some firms may gradually accept the value of quality management practice, while others may reject because of the high cost involved in implementation. Firms who are not taking organizational learning initiatives may not be clear about the value of quality management and are likely to swing in the face of the conflicting strategic choices.

Organizational learning is regarded as historical path dependence by converting past practice theories into daily management practices in the future (Levitt \& March, 1988). Fiol \& Lyles (1985) argue that organizational learning improves performance by acquiring new knowledge. Organizational learning culture can be transformed into innovative power (Bolívar-Ramos et al., 2012). According to Lin \& Ho (2016), the appropriate organizational ambidexterity, exploitative learning and exploratory learning, is regarded as a complementary ability to improve firm performance. Firms try to make use of exploitative and exploratory innovation by organizational learning that can transform institutional pressures and competition into organizational advantages (Dodgson, 1993). Exploitative learning is related to the incremental innovation to improve the existing goods, services and processes, while exploratory learning may lead to technology development and obtain the preemptive advantage. Therefore, firms pursuing ambidextrous learning may achieve higher level of construction quality. Thus, we propose the following hypothesis:

H3: Organizational learning has a positive impact on level of construction quality.

Based on the above hypotheses, the research model is shown in GRAPH 1.

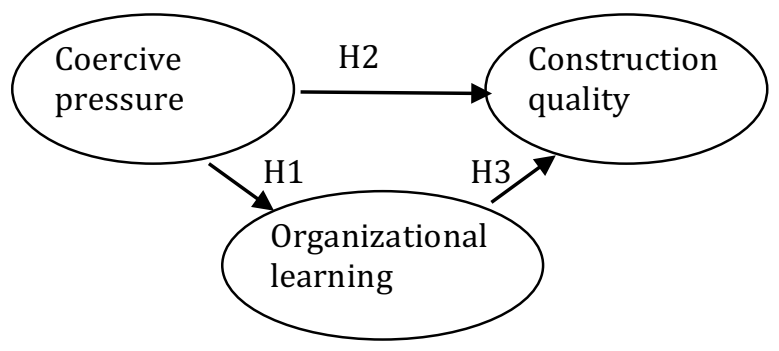

GRAPH 1 Research model

\section{Data collection}

\section{RESEARCH DESIGN}

We collect data via questionnaires in Chinese construction firms located in Taiyuan, Shanxi Province in central China. We choose the construction industry as the research context for the following two reasons: First of all, the construction industry is responsible for high material 
consumption and pollution emission, and once serious quality problems exist, it may lead to serious consequences. Thus the construction industry is under high pressure and strict supervision from the government authorities. Secondly, with the public awareness of the construction quality, firms and government are obliged to learn much more about the factors that affect the level of construction quality.

The target respondents in this research are construction project managers. They have rich knowledge and management experience in the construction industry, and are familiar with the technical details of construction. In addition, they have deep understanding about the industry and firms, which helps to ensure external validity of the research.

Questionnaires were distributed directly to the project managers of construction firms located in Taiyuan, Shanxi province. Before the questionnaires were distributed, the respondents were told the results to be strictly confidential and will only be used for the purpose of scientific research. The survey lasted for 3 months. A total of 300 questionnaires were distributed and 268 valid questionnaires were received with the response rate of $89.3 \%$. In this paper, $t$-test is used to compare the difference between respondents and non-respondents with firm characteristics. The result shows that there is no significant difference, so non-response bias is not a major problem in this study.

\section{Measures}

Variable measurements are designed based on extant scales or the definition of variables in our proposed hypotheses. Each latent variable is measured by at least three observed variables. In addition, the reverse score items were designed in order to reflect the true response of the respondents. Furthermore, in order to improve the accuracy of wording in the questionnaire, we consulted two professors in the field of organizational learning and quality management to adjust and correct the contents and wording of the questionnaire.

The questionnaire consists of two parts. Part 1 is the profile of the firms, construction projects and respondents. Part 2 includes the measurement scale of three latent variables: coercive pressure, organizational learning, and construction quality. The measurement on each latent variable is shown in Table 1. 5-point Likert scale was used for measuring each item of measurement scale, ranging from " $1=$ disagree strongly" to " $5=$ strongly agree". .

Coercive pressure is usually defined as formal or informal pressure imposed by regulatory authorities and government agencies (Steadman et al.,1995; DiMaggio \& Powell, 1983). Based on Zhu \& Sarkis (2007) and Dubey et al. (2015), along with the characteristics of the construction industry, we take the external pressures imposed by government agencies on firms' quality management practice as coercive pressure.

Based on Baker\& Sinkula (1999), we use learning commitment, shared vision and open mindedness to measure organizational learning. Learning commitment means that the firm regards learning as the basic value. Shared vision means that the vision for the future development is shared by members of the firm. Open mindedness means that the firm is free of old and familiar think mode by breaking the rules and encouraging innovation.

Quality can be defined as meeting the legal, aesthetic and functional requirements of a project. Requirements may be simple or complex, or they may be stated in terms of the end results. In construction industry, quality can be defined as meeting the requirements of the designer, constructor and regulatory agencies as well as the owner (Arditi \& Gunaydin, 1997).Based on Fuentes-Fuentes et al.(2011), construction quality is measured via a 4-item scale. 


\subsection{Measure validation}

In this study, SPSS21.0 and AMOS21.0 are used for data analysis. As shown in Table 1, the Cronbach's alpha of each measurement model is more than 0.6 , indicating scale reliability is acceptable. Convergent validity is tested by confirmatory factor analysis (CFA). As shown in Table 1 , The standardized factor loadings are between 0.655 and 0.766 , which are significantly greater than $0.5(\mathrm{p}<0.01)$, indicating the evidence of convergent validity.

Discriminant validity is assessed using the approach suggested by Fornell \& Larcker (1981). The average variance extracted (AVE) of each latent variable was checked and compared with the square of the correlation coefficient between any possible pairs of latent variables. Table 2 lists the correlation coefficient matrix of latent variables. The average variance extracted (AVE) of each latent variable is larger than the square of the correlation coefficient between any possible pairs of latent variables, which provides evidence of discriminant validity.

TABLE 1 Reliability and standardized loadings for measurement model

\begin{tabular}{|c|c|c|c|}
\hline \multirow{2}{*}{$\begin{array}{l}\text { Latent variables } \\
\text { Coercive pressure }\end{array}$} & \multirow{2}{*}{$\begin{array}{l}\text { Items } \\
\text { CP1 }\end{array}$} & \multicolumn{2}{|c|}{ Standardized loadings Cronbach'so } \\
\hline & & $0.721^{* * *}$ & 0.734 \\
\hline & $\mathrm{CP} 2$ & $0.710^{* * *}$ & \\
\hline & CP3 & $0.655^{* * *}$ & \\
\hline \multirow[t]{3}{*}{ Organizational learning } & EOL1 & $0.682^{* * *}$ & 0.741 \\
\hline & EOL2 & $0.766^{* * *}$ & \\
\hline & EOL3 & $0.669^{* * *}$ & \\
\hline \multirow[t]{4}{*}{ Construction quality } & CQ1 & $0.722^{* * *}$ & 0.806 \\
\hline & CQ2 & $0.757^{* * *}$ & \\
\hline & CQ3 & $0.657^{* * *}$ & \\
\hline & CQ4 & $0.718^{* * *}$ & \\
\hline
\end{tabular}

Note : ${ }^{* * *} \mathrm{p}<\overline{0.01}$

TABLE 2 Correlation matrix

\begin{tabular}{llll}
\hline & $\begin{array}{l}\text { Coercive } \\
\text { pressure }\end{array}$ & Organizational learning & $\begin{array}{l}\text { construction } \\
\text { quality }\end{array}$ \\
\hline $\begin{array}{l}\text { Coercive pressure } \\
\begin{array}{l}\text { Organizational } \\
\text { learning }\end{array}\end{array}$ & 0.407 & $(0.584)$ & \\
Construction quality & 0.493 & 0.669 & $(0.510)$
\end{tabular}

Notes: The number on the diagonal line is the average variance extracted (AVE) of the latent variables.

\section{Model fit indices}

\section{RESEARCH RESULTS}

In this study, AMOS21.0 is used to assess the model fit and verify the hypotheses. Before testing the overall model fit, we first check the parameter estimation to avoid the estimated coefficient of the model beyond the acceptable range. Generally speaking, the items leading to offending estimates are as follows: (1) there are negative or non-significant error variances; (2) the standardized factor loading coefficients are greater than or too close to 1 ; (3) there are large standard errors (Bagozzi \& Yi, 1988). 


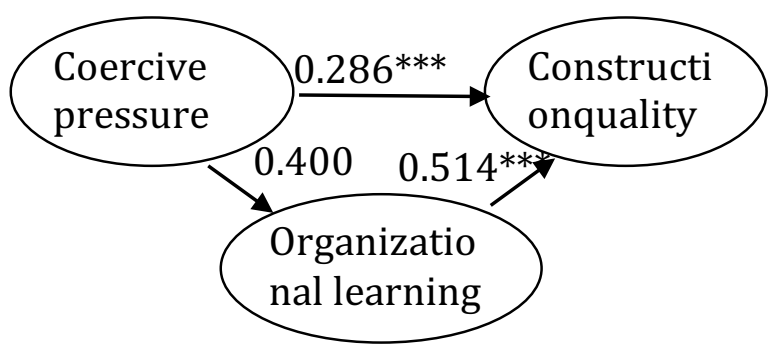

GRAPH 2 Path diagram of the research model

Notes: (1) Fit indices: Chi-square $=56.609, \mathrm{df}=31, \mathrm{p}$-value $=0.003, \mathrm{GFI}=0.961, \mathrm{AGFI}=0.930$, $\mathrm{RMR}=0.01, \mathrm{RMSEA}=0.056, \mathrm{NNFI}=0.957, \mathrm{CFI}=0.970, \mathrm{IFI}=0.971, \mathrm{PGFI}=0.541, \mathrm{PNFI}=0.646$;

$(2)^{* * *} \mathrm{p}<0.01$

TABLE 3 Results of hypotheses tests

\begin{tabular}{lll}
\hline Hypothesis & Standardized solution (t-valu $\epsilon$ Result \\
\hline H1:Coercive pressure $\rightarrow$ Organizational learning & $0.400^{* * *}(4.596)$ & Support \\
H2:Coercive pressure $\rightarrow$ Construction quality & $0.286^{* * *}(3.580)$ & Support \\
H3:Organizational learning $\rightarrow$ Construction quality & $0.514^{* * *}(5.790)$ & Support \\
\hline
\end{tabular}

Notes: ${ }^{* * *} \mathrm{p}<0.01$

The error variance in this model is ranging from 0.015 to 0.038 without negative or nonsignificant error variances. The absolute values of standardized factor loading are between 0.654 and 0.785 , which do not exceed 0.8. In addition, the standard errors are between 0.014 and 0.125 . All of the above results show that offending estimates don't exist and can be used to test the overall model fit. As is shown in Graph 2, the model fit indices are all in the acceptable range, indicating the model is fit with the data.

\section{Results of hypotheses tests and discussion}

Graph 2 and Table 3 show the path coefficients and significance of the research model. Coercive pressure positively affects organizational learning (the standardize path coefficient is $0.400, \mathrm{P}<0.01$ ). In addition, coercive pressure also positively affects construction quality (the standardized path coefficient is $0.286, \mathrm{P}<0.01$ ). $\mathrm{H} 1$ and $\mathrm{H} 2$ thus are supported. The coercive pressure effectively leads to the adoption of the quality management practices by firms. Therefore, the introduction of laws, regulations and policies encouraging firms adopt quality management practices may promote construction quality. Although coercive pressure may lead firms to focus on improving the level of construction quality, it is impossible to realize the improvement on construction quality without adopting appropriate construction technology. Thus, organizational learning may serve as a bridge between coercive pressure and construction quality.

H3 predicts that firms focusing on organizational learning will contribute to higher level of construction quality, which is also confirmed in our analysis (the standardized path coefficient is $0.514, \mathrm{P}<0.01$ ). Organizational learning has a positive impact on the level of construction quality, which provides the answer to "why do firms facing the same coercive pressure in the organization field have different level of construction quality". For firms in the same organizational field, the heterogeneity of construction quality is not only related to passive response to coercive pressure (Oliver, 1991), but also related to organizational characteristics. Therefore, even if the same level of coercive pressure is imposed on two firms, the perceptions 
and responses of the two firms may be different (Delmas \& Toffel, 2004). Firms assign the coercive pressure to different departments, and each department describes these pressures according to their characteristics. For example, the legal department interprets the risks and responsibilities, and the sales department pays attention to the potential income. The unique organizational characteristics affect the transformation and interpretation of coercive pressure in the firm. Organizational learning can transform coercive pressure into sources of innovation, and then improves organizational performance (Bolivar-Ramos et al., 2012). Therefore, to some extent organizational learning reflects the ability that firms transform coercive pressure to construction quality. Firms with high level of organizational learning are more rational for interpreting institutional discourse and are not easy to be dictated by various departments. Rather such firms pay more attention to quality problems, try to turn them into organizational culture and rationally face the choice of pursuing profits and ensuring quality. In contrast, due to the difficulty of integrating innovation into the process of production or service, firms with low level of organizational learning may prefer to benefits from short term, resulting in unsustainable revenue in the long term (Lin \& Ho, 2016).

\section{Conclusions and managerial implications}

\section{CONCLUSIONS}

Based on previous research, a conceptual model on the relationship among coercive pressure, organizational learning and construction quality is developed. Data from construction firms located in Taiyuan City, Shanxi province are collected by questionnaire, which are analyzed with structural equation model. The results show that: (1) coercive pressure has a significant positive impact on organizational learning; (2) organizational learning has a significant positive impact on construction quality; (3) organizational learning plays a mediating role on the relationship between coercive pressure and construction quality.

The empirical results imply that construction quality is affected by both coercive pressure and organizational learning. Firms who adopt the passive strategy to deal with coercive pressure cannot achieve competitive advantage. Zhu \& Sarkis (2007) argue that the adoption of appropriate organizational policies may enhance the legitimacy. Firms should encourage organization members to learn rules and regulations related to construction quality, adopt successful quality management practices, learn experiences and lessons from them. Firms should try to fully understand the interpretation of the institutional discourse, identify the contradictory coercive pressure as far as possible through the internal communication and organizational learning, enabling firms to achieve sustainable competitive advantage and promote continuous improvement on construction quality.

If firms want to improve the construction quality, they should also pay attention to the pressures from the government. For firms in developing countries, coercive pressure is a key factor driving quality management practices. The government usually has two functions: using legislation as a way of changing the structure and behavior of firms, and implementing legislation through authority and supervision. The legislation represents the expectations of the individual and the society, which is related to a particular concept or value. In addition, complying with legislations may enhance the legitimacy of firms aimed at improving the construction quality.

\section{Research limitations and directions for further research}

As with other research, this paper has several limitations. First, the sample firms in construction industry located in Taiyuan City, Shanxi Province in central China were chosen based on convenience and therefore not random samples. The research results may not apply to other industries or other regions. Future research should extend the samples which include 
more industries and other regions in China. Second, this paper uses cross-sectional data rather than longitudinal data, so the results cannot be interpreted as the causality between variables. It is suggested that the future research should collect longitudinal data to examine the causal relationship among coercive pressure, organizational learning and construction quality.

\section{References}

Arditi, D., \& Gunaydin, H. M. (1997). Total quality management in the construction process. International Journal of Project Management,15(4), 235-243.

Ashforth, B. E., \& Gibbs, B. W. (1990). The double-edge of organizational legitimation. Organization Science, 1(2), 177-194. Richard P. Bagozzi, \& Youjae Yi. (1988). On the evaluation of structural equation models. Journal of the Academy of Marketing Science, 16(1), 74-94.

Baker, W. E., \& Sinkula, J. M. (1999). The synergistic effect of market orientation and learning orientation on organizational performance. Journal of the Academy of Marketing Science, 27(4), 411-427.

Berrone, P., \& Gomez-Mejia, L. R. (2009). Environmental performance and executive compensation: an integrated agency-institutional perspective. Academy of Management Journal, 52(1), 103-126.

Bolívar-Ramos, M. T., García-Morales, V. J., \& García-Sánchez, E. (2012). Technological distinctive competencies and organizational learning: effects on organizational innovation to improve firm performance. Journal of Engineering \& Technology Management, 29(3), 331-357.

Clemens, B., \& Douglas, T. J. (2006). Does coercion drive firms to adopt 'voluntary' green initiatives? relationships among coercion, superior firm resources, and voluntary green initiatives. Journal of Business Research,59(4), 483491.

Delmas, M., \& Toffel, M. W. (2004). Stakeholders and environmental management practices: an institutional framework. Business Strategy \& the Environment, 13(4), 209-222.

Dimaggio, P. J., \& Powell, W. W. (1983). The iron cage revisited: institutional isomorphism and collective rationality in organizational fields. American Sociological Review, 48(2), 147-160.

Dodgson, M. (1993). Organizational learning: a review of some literatures. Organization Studies, 14(3), págs. 375394. Dowling, J., \& Pfeffer, J. (1975). Organizational legitimacy: social values and organizational behavior. Pacific Sociological Review, 18(1), 122-136.

Dubey, R., Gunasekaran, A., \& Ali, S. S. (2015). Exploring the relationship between leadership, operational practices, institutional pressures and environmental performance: a framework for green supply chain. International Journal of Production Economics, 160, 120-132.

Fiol,C.M., Lyles,M.A. (1985).Organizational Learning. Academy of Management Review, 10 (4),803-813.

Fornell, C., \& Larcker, D. F. (1981). Evaluating structural equation models with unobservable variables and measurement error. Journal of Marketing Research, 18(1), 39-50..

Fuentes-Fuentes, M. M., Lloréns-Montes, F. J., Molina-Fernández, L. M., \& Albacete-Sáez, C. A. (2011). Environmentquality management coalignment across industrial contexts: an empirical investigation of performance implications. Industrial Marketing Management, 40(5), 730-742.

Huber, G. (1991).Organizational learning: The Contribution Processes and the Literatures. Organization Science, 2(1),88-115.

Ingram, P., \& Silverman, B. S. (2002). The new institutionalism in strategic management /. The new institutionalism in strategic management. JAI.

Jennings, P. D., \& Zandbergen, P. A. (1995). Ecologically sustainable organizations: an institutional approach. Academy of Management Review, 20(4), 1015-1052..

Kassinis, G., \& Vafeas, N. (2006). Stakeholder pressures and environmental performance. Academy of Management Journal, 49(1), 145-159.

Khanna, M. (2002). Corporate environmental management: regulatory and market-based incentives. Land Economics, 78(4), 539-558.

Lee, J., Veloso, F. M., Hounshell, D. A., \& Rubin, E. S. (2010). Forcing technological change: a case of automobile emissions control technology development in the us. Technovation, 30(4), 249-264.

Levitt,B., March, J.G. (1988).Organizational Learning.Annual Review of Sociology, 14(3),319-340. 
Lin, L. H., \& Ho, Y. L. (2016). Institutional pressures and environmental performance in the global automotive industry: the mediating role of organizational ambidexterity. Long Range Planning, 49(6), 764-775.

March, J.G. (1991).Exploration and Exploitation in Organizational Learning.Organization Science, 2(1):71-87.

Oliver, C. (1991). Strategic responses to institutional processes. Academy of Management Review, 16(1), $145-179$.

Roome, N., \& Wijen, F. (2006). Stakeholder power and organizational learning in corporate environmental management. Ulb Institutional Repository, 27(2), 235-263.

Slater, S. F., \& Narver, J. C. (1995). Market orientation and the learning organization. Journal of Marketing, 59(3), 63-74.

Steadman, M. E., Zimmerer, T. W., \& Green, R. F. (1995). Pressures from stakeholders hit japanese companies. Long Range Planning, 28(6), 29-37.

Suchman, M. C. (1995). Managing legitimacy: strategic and institutional approaches. Academy of Management Review, 20(3), 571-610.

Taylor, M. R., Rubin, E. S., \& Hounshell, D. A. (2005). Control of so\{sub 2 emissions from power plants: a case of induced technological innovation in the us. Technological Forecasting \& Social Change, 72(6), 697-718.

Taylor, M. R., Rubin, E. S., \& Hounshell, D. A. (2003). Effect of government actions on technological innovation for so2 control. Environmental Science \& Technology, 37(20), 4527-34.

Yiu, D., \& Makino, S. (2002). The choice between joint venture and wholly owned subsidiary: an institutional perspective. Organization Science, 13(6), 667-683.

Zhu, Q., Sarkis, J., \& Lai, K. H. (2012). Internationalization and environmentally-related organizational learning among chinese manufacturers. Technological Forecasting \& Social Change, 79(1), 142-154.

Qinghua Zhu, \& Joseph Sarkis. (2007). The moderating effects of institutional pressures on emergent green supply chain practices and performance. International Journal of Production Research, 45(18-19), 4333-4355. 